\title{
Wielkomiejska mozaika
}

Magdalena Saryusz-Wolska 


\section{Roztrząsania i rozbiory}

\section{Wielkomiejska mozaika}

Magdalena Saryusz-Wolska

TEKSTY DRUGIE 2017, NR 5, S. 168-176

DOI: $10.18318 /$ td. $2017 \cdot 5 \cdot 10$

$\mathbf{K}$

siążka Aliny Molisak żydowska Warszawa - żydowski Berlin. Literacki portret miasta $w$ pierwszej połowie XX wieku jest dokładnie tym, co obiecuje tytuł, czyli omówieniem przedwojennych obrazów żydowskiego życia. Dodam, że jest to tekst znakomicie, wartko wręcz napisany, z klarowną tezą, precyzyjnie skonstruowany. Autorka już na pierwszych stronach wyjaśnia punkt wyjścia swoich rozważań, pisząc o analizowanych tekstach: „Z jednej strony [ich] autorzy posługują się rozmaitymi schematami i stereotypami, służącymi często egzotyzacji Wchodu, z drugiej zaś - napotykamy w tekstach spojrzenie na różne wersje tożsamości zachodnioeuropejskiej diaspory, postrzeganej oczyma przybyszów ze Wschodu [...]" (s. 8). Na dalszych stronach tropi owe schematy, stereotypy i spojrzenia, zawarte w żydowskiej, polsko-żydowskiej i niemiecko-żydowskiej literaturze o przedwojennej Warszawie i przedwojennym Berlinie. Oś „Wschód-Zachód” nieustannie powraca jako centralny wzorzec orientacyjny, wyznaczający projekty tożsamościowe, zawarte w badanych tekstach. Charakterystyczna jest też konstrukcja logiczna zawarta w powyższym,

Magdalena Saryusz-

-Wolska - dr hab., kulturoznawczyni i socjolożka, pracuje w Instytucie Kultury Współczesnej UŁ oraz w Niemieckim Instytucie Historycznym w Warszawie, bada pamięć kulturową, filmy historyczne i historię wizualną. Autorka m.in.Spotkania czasu z miejscem. Studia o pamięci i miastach (2011), Ikony normalizacji. Kultury wizualne Niemiec 1945-1949 (2017, 2. wyd.), Modi memorandi.Leksykon kultury pamięci (2014, red. z R. Traba). Kontakt: magdalena. saryusz-wolska@uni. lodz.pl 
programowym zdaniu, wyrażająca się w sformułowaniu „z jednej strony..., z drugiej zaś". Molisak zdaje się bowiem obracać przedmiot swoich badań na wszystkie strony, oglądać go z wielu perspektyw, przedstawiając w ten sposób złożoność przedwojennej kultury żydowskiej w Warszawie i Berlinie. Nic nie jest tu jednoznaczne: motywy asymilacji i akulturacji przeplatają się z poczuciem obcości i wykluczenia, a podobieństwa dekonstruowane są przez wskazywanie różnic. Jak napisała w zakończeniu: „W obu przypadkach, zarówno żydowskiego Berlina, jak i żydowskiej Warszawy, zapisy literackie tworzą mozaikę skomplikowaną, ujawniającą wieloaspektowość i złożoność obrazów miejskich przestrzeni [...]" (s. 344).

Mozaikowość zjawiska, o którym wspomina Molisak, byłaby niemożliwa do ukazania, gdyby nie precyzyjna kompozycja omawianej tu książki. Oprócz rozdziałów wprowadzającego i podsumowującego zawiera ona pięć rozdziałów poświęconych różnym aspektom wielkomiejskiego życia przedwojennych Żydów: aktywności politycznej, praktykom religijnym, przestępczości, miejscom wspólnego/osobnego życia Żydów i nie-Żydów oraz różnym aspektom imigracji do miast i emigracji z nich. Każdy rozdział rozpoczyna się od ogólnego zarysowania problemu i jego historycznych kontekstów, następnie zaś autorka przechodzi do analizy poszczególnych tekstów literackich. Kluczem wyboru są opisywane miejsca i zjawiska, nie zaś tożsamość autorów czy język publikacji (nie analizuje ona literatury pisanej po hebrajsku). Pisze np. o polskojęzycznych tekstach Jakuba Appenszlaka, niemieckojęzycznej powieści Adolfa Sommerfelda Das Ghetto von Berlin, a także o licznych świadectwach literatury pisanej w jidysz. Ciekawe są zwłaszcza spojrzenia autorów berlińskich spoglądających na żydowską Warszawę (Alfred Döblin) i polskich, którzy przedstawiali Berlin (Antoni Sobański). W ten sposób Molisak kreśli wieloperspektywiczny obraz dzielnic żydowskich w obu miastach. Fragmenty poświęcone Warszawie i Berlinowi przeplatają się. Nie porównuje ona utworów przez ich proste zestawienie, lecz raczej komponuje wielowątkowe kłącze, podporządkowując fragmenty analizy własnej narracji o przedwojennych miastach.

Książka Aliny Molisak jest jednym z niewielu opracowań kultury polsko-niemieckiej (wśród prac opublikowanych w ostatnim czasie należałoby też wymienić Nekroperformans Doroty Sajewskiej'), w których komparatystyczne podejście nie opiera się na wyborze tekstów polskich i niemieckich,

1 D. Sajewska Nekroperformans. Kulturowa rekonstrukcja teatru Wielkiej Wojny, Instytut Teatralny im. Z. Raszewskiego, Warszawa 2016. 
ich osobnym omówieniu, a następnie porównaniu, lecz wyrasta niejako z samej specyfiki tematu. Sploty i wzajemne powiązania kultury polskich i niemieckich Żydów są tak silne - choćby ze względu na kolejne fale migracji - że wspólny ich opis wydaje się przedsięwzięciem poniekąd oczywistym i wpisanym w istotę zjawiska². Molisak inspiruje się w szczególności koncepcją contact zone Mary Louise Pratt, dowodząc, że funkcję tę spełniały wyodrębnione dzielnice żydowskie, obecne w obu miastach. Choć autorka nieco więcej miejsca poświęca tekstom warszawskim, to trafnie uzasadnia potrzebę łączenia analizy z utworami berlińskimi: „Niemcy, a przede wszystkim Berlin, były, podobnie jak Warszawa, istotnym miejscem kształtowania się nowoczesnej żydowskiej kultury, w tym także literatury powstającej po hebrajsku, po niemiecku i w jidysz. [...] właśnie niemiecka stolica była miejscem spotkania żydowskiego Zachodu i Wschodu" (s. 24-25). Dialektyki Wschodu i Zachodu, swojskości i egzotyki, auto-i heterostereotypów żydowskich stanowi jeden z głównych tematów Żydowskiej warszawy - żydowskiego Berlina. Oprócz licznych podobieństw w obrazie dzielnic żydowskich obu miast autorka wskazuje także na wiele różnic, uwidaczniających się choćby w odmiennych formach zaangażowania w życie polityczne i wielości praktyk religijnych.

Opowieść o przedwojennej literaturze siłą rzeczy pełni także funkcje opowieści o przeszłości. Molisak wprowadza czytelnika w kontekst historyczny, szkicując krajobraz partii politycznych i organizacji, w których działali Żydzi: m.in. Bundu w Warszawie czy Zrzeszenia Obywateli Niemieckich Wyznania żydowskiego w Berlinie (Central-Verein deutscher Staatsbürger jüdischen Glaubens) ${ }^{3}$. Objaśnia w skrócie główne nurty judaizmu i różnice między nimi (judaizm reformowany w Niemczech czy ruch chasydzki na ziemiach polskich). Kreśli historię społeczną żydowskiej przestępczości, opisuje miejsca, w których w Berlinie i Warszawie Żydzi żyli wspólnie z nie-Żydami, wreszcie omawia główne fale emigracji żydowskich aż do wybuchu II wojny światowej. Informacje te zawarte są na ogół na pierwszych stronach poszczególnych rozdziałów, przedstawiają czytelnikowi nieobeznanemu z historią Żydów w Niemczech i Polsce tło omawianej literatury. W pasażach, w których Molisak interpretuje utwory literackie, opis historii i analiza tekstu nierzadko splatają się ze sobą. Wiele jest zatem w książce zdań takich

2 Por. K. Steffen żydzi, w: Polsko-niemieckie miejsca pamięci. Wspólne/osobne, t. 1., red. R. Traba, H. Henning Hahn, współpr. K. Kończal, M. Górny, Scholar, Warszawa 2015.

3 W dosłownym tłumaczeniu nazwy z niemieckiego powinno być "wiary żydowskiej”. 
jak: „Przynależność poddanych rosyjskiego imperium sprawiała, że «ponury nastrój żałoby panował wśród polskich i rosyjskich żydów»" (s. 306). Cytat w powyższym cytacie pochodzi z powieści Izraela Joszuy Singera Rodzina Karwowskich. Autorka może mieć tu na myśli świat przedstawiony w powieści, realia historyczne, jak również jedno i drugie.

W monografii takiej jak Żydowska Warszawa - żydowski Berlin podobne dwuznaczności są trudne do uniknięcia bez szkody dla stylu, jednak liczne fragmenty, w których przedwojenna mentalność żydowska kreślona jest na podstawie tekstu literackiego, skłaniają do szerszej refleksji o statusie literatury jako źródła historycznego. Historycy przeważnie odmawiają zjawiskom literackim statusu faktów ${ }^{4}$, co siłą rzeczy sprawia, że rzadko sięgają do literatury w celu opisania minionej rzeczywistości. Tekst literacki może być jednak - jak zauważa Adam Kożuchowski - „źródłem wyjątkowo cennym jako świadectwo wyobrażeń, jakie w danym miejscu i czasie powstawały i funkcjonowały w odniesieniu do świata otaczającego autora oraz jego czytelników"5. Dokładnie tym tropem podąża Molisak, jakkolwiek badaczka lakonicznie komentuje własną metodę. Tymczasem refleksja o związkach między historią i literaturą ma bogatą tradycję. Whumanistyce niemieckojęzycznej temat ten podnosili tak wybitni teoretycy jak György Lukács ${ }^{6}$ czy Hans Robert Jauss ${ }^{7}$. W Polsce w połowie lat 6o. XX wieku Jerzy Maternicki przedstawiał praktyczne rozważania na temat literatury pięknej w nauczaniu historii ${ }^{8}$, natomiast nieco ponad dekadę później odbyła się przełomowa konferencja w Instytucie Badań Literackich PAN „Dzieło literackie jako źródło historyczne”,

4 A. Kożuchowski "Zmyślenia i prawda”, czyli dzieło literackie jako źródło historyczne, „Pamiętnik Literacki" 2005 Z. 1 (96), s. 7.

5 Tamże, s. 8.

6 Por. G. Lukács Klasyczna postać powieści historycznej, w: tegoż Od Goethego do Balzaka: studia z historii literatury XVIII i XIX w., przeł. Z. Herbert, Państwowy Instytut Wydawniczy, Warszawa 1958, s. 237-318.

7 Por. H.R. Jauss Zastosowanie fikcji w formach oglądu i przedstawiania historii, przeł. J. Kałążny, w: Opowiadanie historii w niemieckiej refleksji teoretyczno-historycznej i literaturoznawczej od oświecenia do współczesności, red. J. Kałążny, Wydawnictwo Poznańskie: Poznań 2003, s. 394-428. Por. też A. Kożuchowski „Zmyślenia i prawda”..., s. 10 i n.

8 J. Maternicki Literatura piękna w nauczaniu historii, Państwowe Zakłady Wydawnictw Szkolnych, Warszawa 1964 .

9 Dzieło literackie jakoźródło historyczne: [materiałyz konferencji naukowej, Warszawa 14-16 grudnia 1976 r.], red. Z. Stefanowska, J. Sławiński, Czytelnik, Warszawa 1978. 
gromadząca takich badaczy jak Michał Głowiński, Jerzy Holzer, Jerzy Topolski czy Bronisław Geremek. Ostatnie nazwisko jest o tyle znaczące, że namysł nad możliwością wykorzystania tekstów fikcjonalnych w badaniach historycznych wyrasta w dużej mierze z dorobku szkoły Annales i badań nad historią codzienności. Kiedy zatem Molisak analizuje np. literackie obrazy żydowskich prostytutek, komentuje je nolens volens z pozycji metodologa historii: „Nie mamy właściwie świadectw pochodzących bezpośrednio od prostytutek, niemniej warto zauważyć, że problematyzacja kwestii prostytucji czy handlu kobietami niejednokrotnie stawała się tematem tekstów literackich [...]" (s. 161) ${ }^{10}$. Strategia analityczna autorki polega w dużej mierze na konfrontacji literatury z opracowaniami historiograficznymi, ale bynajmniej nie po to, by ustalać "prawdziwość" analizowanych reprezentacji, lecz raczej by uzyskać pełniejszy obraz omawianego tematu i zagłębić się w kontekst i okoliczności powstawania i recepcji dyskutowanych utworów.

W milczącej zgodzie z istniejącą refleksją metodologiczną autorka następująco deklaruje swój cel: „[...] możemy spróbować czytać teksty w taki sposób, by uwypuklone zostały nie tylko «praktyki znaczeniotwórcze» (Culler), ale by możliwe stało się również porównanie rozmaicie (fikcjonalnie i nie) zapisanych doświadczeń różnych grup etnicznych. W rezultacie odczytanie tekstów literackich pochodzących z pierwszej połowy XX wieku [...] pozwoli w jakiejś mierze sportretować tożsamość kulturową konkretnej grupy" (s. 19). Łączenie analizy literackiej z narracją historiograficzną to zatem rezultat przyjętej, ale szerzej nieskomentowanej przez Molisak metody (być może uznanej za oczywistość), która pozwala jej na jednym poziomie omawiać teksty fikcjonalne i niefikcjonalne - nierzadko zresztą pisane przez tych samych autorów, jak w wypadku Döblina czy Appenszlaka. Podejście to stosuje autorka konsekwentnie, pokazując specyfikę przedwojennych tożsamości żydowskich, przedstawionych w omawianych tekstach. Mimo że rozdziały uporządkowane są wedle różnych sfer życia (polityka, religia, przestępczość, akulturacja, migracja), to każdą z nich Molisak objaśnia historycznie.

Badaczka dochodzi do wniosku, że w obu miastach, Warszawie i Berlinie, doświadczenie wielkomiejskie sprzyja formowaniu się tożsamości „pomiędzy” (s. 341), oddziałujących w „trzeciej przestrzeni” (Homi Bhabha). riografia i mitologia kobiecości. Powieściopisarstwo Teodora Parnickiego, Wydawnictwo UMK w Toruniu, Toruń 2017, s. 9-42. 
Wykorzystanie tekstów autorów polskich i niemieckich, opisujących dzielnice żydowskie w dwóch stolicach, pozwala jej także na wnioski dotyczące relacji między poszczególnymi grupami. Konkluzje te są szczególnie wyraziste w odniesieniu do stosunków polsko-żydowskich: „żydowscy mieszkańcy tych ziem nie stali się w oczach Polaków współobywatelami" (s. 326). Cytat ten pochodzi z analizy manifestu Appenszlaka Oskarżam! z 1918 roku, ale z powodzeniem pasowałby także do wielu innych interpretacji zawartych w książce Molisak. Świadectwa asymetrycznych relacji między Polakami i Żydami autorka dostrzega bowiem zarówno w tekstach polskich (m.in. opis dzielnicy żydowskiej w Ludziach bezdomnych Żeromskiego), jak i w literaturze i publicystyce żydowskiej czy polsko-żydowskiej.

Z omówień poszczególnych tekstów literackich jednoznacznie wynika, że wielkomiejska tożsamość przedwojennych Żydów stoi w centrum zainteresowania badaczki, jednak we wprowadzeniu deklaruje ona przede wszystkim inspiracje geopoetyką i socjologią miasta. Podejścia te nie są jednak przez nią konsekwentnie wykorzystywane - zapewne dlatego, że jedynie częściowo wpisują się one w formułowane w książce cele badawcze. Tymczasem, podążając dalej tropem geopoetyki, można by się też zastanowić nad tym, jakie mapy mentalne żydowskich dzielnic kreślą autorzy piszący o Berlinie i Warszawie, jak złożony jest miejski palimpsest tych tekstów i z jakich warstw się składa, czy wreszcie: jak funkcjonują tamtejsze heterotopie. Wbrew wstępnym deklaracjom, analizy przedstawione w Żydowskiej Warszawie - żydowskim Berlinie koncentrują się jednak wokół innych zagadnień - na szczęście przeskok tematyczny odbywa się bez wielkiej szkody dla przyjemności w lekturze. Molisak świadomie zresztą pomija wiele możliwych pól refleksji, sygnalizując je jedynie w przypisach. Z jednej strony tekst zachowuje dzięki temu wewnętrzną spójność, unika dygresji i wprowadzania nowych tematów; z drugiej zaś otwiera wiele furtek dla dalszych pytań, komentarzy i dopowiedzeń.

Jedną z często wzmiankowanych w książce spraw jest wielojęzyczność żydowskiej literatury. Molisak zaznacza, że pracuje z literaturą pisaną po niemiecku, polsku i w jidysz (raczej nie po hebrajsku), komentuje też wpływy jidysz na polszczyznę/niemczyznę. Wielojęzyczność zdaje się cechą charakterystyczną obu przedwojennych metropolii, widoczną nie tylko w praktykach komunikacyjnych pisarzy i publicystów, ale także przedstawianą w poszczególnych tekstach literackich. Opisy żydowskiej tożsamości widzianej (czy raczej: słyszanej) przez pryzmat odmienności językowej Molisak odnajduje u wielu omawianych autorów: Jakuba Appenszlaka (Piętra. Dom na Bielańskiej), Szaloma Asza (Warszawa), Poli Gojawczyńskiej (Dziewczęta z Nowolipek), 
Zbigniewa Uniłowskiego (Wspólny pokój), Szolem-Alejchema (Marienbad), Adolfa Sommerfelda (Das Ghetto von Berlin). Pojawiają się takie pojęcia jak: "gwara”, „melodia”, „zgiełk”, czyli skoncentrowane przede wszystkim na brzmieniu jidysz i hebrajskiego. Rzadko natomiast na plan pierwszy wysuwa się graficzna odmienność pisma. Napisy i szyldy pisane w odmiennym języku Molisak dostrzega głównie w powieści Tohuwabohu Sammy'ego Gronemanna. W oczach narratora wzmacniają one egzotykę Ostjuden w Berlinie.

Kwestia pisma jest o tyle istotna, że wiąże się z intermedialnym doświadczeniem wielkiego miasta, w którym nie tylko się mówi i czyta, ale także słucha radia czy chadza do kina. Ten element wielkomiejskiego życia Molisak identyfikuje przede wszystkim w kontekście antysemityzmu i zagrożeń tożsamości. Za Moniką Bednarczuk podaje, że zwłaszcza w oczach polskich autorów prawicowych media „wraz z hegemonią środowisk żydowskich nad literaturą przyczyniają się do moralnej katastrofy i deformowania «prawdziwej polskości»" (s. 317) ${ }^{11}$. Śladowa obecność nowych w tamtym czasie mediów masowych w opisach żydowskiej wielkomiejskości każe przypuszczać, że istotnym elementem tożsamości, którą ",portretuje” (jak sama to nazywa) Molisak, jest tradycja. Odwołania do niej autorka analizuje przede wszystkim w rozdziale poświęconym praktykom religijnym przedwojennych Żydów w Berlinie i Warszawie.

Medialność (w tym: literackość) miasta to także zagadnienie, które doczekało się bogatej refleksji teoretycznej. W polskiej humanistyce klasyczną wręcz pozycją jest tom Pisanie miasta - czytanie miasta pod redakcją Anny Zeidler-Janiszewskiej ${ }^{12}$.To, co rzuca się w oczy podczas lektury tej dwudziestoletniej już pozycji, to po pierwsze, dominujące zainteresowanie ówczesnych badaczy miastami zachodnimi, po drugie, szeroka refleksja nad wizualnością i haptycznością miasta - zwłaszcza w zestawieniu ze sferą audialną. W porównaniu z tamtą książką, która stanowiła świadectwo stanu badań końca XX wieku, w nowszych (nie tylko polskich) badaniach miejskiej medialności i literackości widać coraz większe zainteresowanie Europą Środkowo-Wschodnią. W humanistyce niemieckojęzycznej reprezentują je głównie - kilkakrotnie przywoływani przez Molisak - Karl Schlögel (w Polsce ukazały się m.in.

Cyt. z: M. Bednarczuk Warszawa jako antywartość: stolica w międzywojennym piśmiennictwie prawicowym, w: Obrazy stolic europejskich w piśmiennictwie polskim, red. A. Tyszka, Wydawnictwo Akademii Humanistyczno-Ekonomicznej, Łódź 2010, s. 318.

12 Pisanie miasta - czytanie miasta, red. A. Zeidler-Janiszewska, Fundacja Humaniorum, Poznań 1997. 
W przestrzeni czas czytamy i środek leży na Wschodzie ${ }^{13}$ ) oraz Moritz Csáky (Das Gedächtnis der Städte $e^{14}$ ). Ten ostatni, austriacki kulturoznawca, zwracał uwagę na istotność kultury żydowskiej - zwłaszcza literatury, publicystyki i teatru dla dyskursywnego tworu, jakim jest Europa Środkowa czy Europa Centralna. W tej części świata kultura Żydów pełni kluczową rolę w konstruowaniu wyobrażeń o grupach własnych i obcych. Podobnie jak czyni to Molisak w kontekście Warszawy i Berlina, Csáky podkreślał asymetrię w relacjach Żydów i nie-Żydów oraz hegemonialne praktyki grup dominujących (w imperium Austro-Węgierskim, które stało w centrum jego uwagi, była to przede wszystkim ludność niemieckojęzyczna) ${ }^{15}$. Definiowały one tożsamości kulturowe na wielu poziomach, przenikając także do tekstów literackich. Ten sposób myślenia wydaje się także bliski autorce Żydowskiej warszawy - żydowskiego Berlina, która podkreśla asymetryczne relacje poszczególnych grup, dowodząc m.in., że „żydowscy twórcy znali polską kulturę", natomiast „trudno byłoby wskazać (poza wąskim gronem) polskich odbiorców kultury żydowskiej" (s. 320-321).

Książka Molisak jest ciekawym, przystępnie i wciągająco napisanym studium przedwojennej mentalności w wielkomiejskim i wielokulturowym środowisku. Nie spełnia wprawdzie wszystkich obietnic złożonych we wprowadzeniu, ale za to niespodziewanie realizuje inne, które wyłaniają się w toku lektury. Otwiera także pole dla kolejnych badań i prowokuje do stawiania dalszych pytań - także tych związanych ze współczesną (nie)obecnością Żydów w kulturach niemieckiej i polskiej.

13 K. Schlögel W przestrzeni czas czytamy. O historii cywilizacji i geopolityce, przeł. I. Drozdowska, Ł. Musiał, posł. H. Orłowski, Wydawnictwo Poznańskie, Poznań 2009; tegoż Środek leży na wschodzie. Europa w stadium przejściowym, przeł. A. Kopacki, Warszawa 2005.

M. Csáky Das Gedächtnis der Städte. Kulturelle Verflechtungen - Wen und die urbanen Milieus in Zentraleuropa, Böhlau Verlag, Wien, Köln, Weimar 2009; w języku polskim por. tegoż Historia i pamięć. Pamiętanie istrategie pamięci wnarracji historycznej: przykład Europy Centralnej, przeł. K. Popławska, w: (Kon)teksty pamięci. Antologia, red. K. Kończal, Narodowe Centrum Kultury, Warszawa 2014, S. 205-223. 


\section{Abstract}

\section{Magdalena Saryusz-Wolska}

UNIVERSITYOF ŁÓDŹ

The Metropolitan Mosaic

Review: Alina Molisak Żydowska Warszawa - żydowski Berlin: Literacki portret miasta w pierwszej połowie XX wieku [Jewish Warsaw - Jewish Berlin: A Literary Portrait of Cities in the First Half of the Twentieth Century], Wydawnictwo IBL, Warsaw 2016

\section{Keywords}

memory of the city, Jewish literature, literature of Warsaw, literature of Berlin 